Resumen por el autor, Joseph H. Bodine,

Universidad de Pennsylvania.

Factores que influyen en el contenido acuoso y la marcha del metabolismo en ciertos ortópteros.

Las observaciones dadas a conocer en el presente trabajo tienden a indicar que en ciertos ortópteros (saltamontes) el contenido de agua en el cuerpo es característico para una especie particular, disminuyendo con la edad y con el aumento de peso del cuerpo. Los efectos de temperaturas bajas y del hambre sobre el contenido de agua han sido también estudiados, y los resultados indican que en ambos casos tiene lugar una disminución en la cantidad de agua contenida en el cuerpo.

También se dan a conocer las cantidades de anhidrido carbonico producidas en diferentes especies de saltamontes, y estos datos indican que las diversas especies poseen diferentes cantidades de cambios respiratorios y que en todo caso estas cantidades son mayores en los individuos mas jovenes. Los efectos de la temperatura sobre la cantidad de anhidrido carbónico producido indican que el aumento de temperatura parecen aumentar la cantidad de dicho gas, mientras que temperaturas mas bajas producen el efecto contrario. La infestión de alimento en anirnales hambrientos aumenta la cantidad de $\mathrm{CO}_{2}$ producido. El autor ha comparado los datos obtenidos en su estudio de los ortópteros con los de los mamíferos, encontrando sorprendentes analogías. 
ACTHOR'S ABSTRACT OF THIS PAPEK ISSUES BY THE BIBLIOCRAPHIC SERTICE, NOVEMBER 1

\title{
FACTORS INFLUENCING THE WATER CONTENT AND THE RATE OF METABOLISM OF CERTAIN ORTHOPTERA
}

\author{
JOSEPH HALL BODINE \\ Zoological Laboralory, University of Pennsylvania
}

SIX FIGURES

CONTENTS

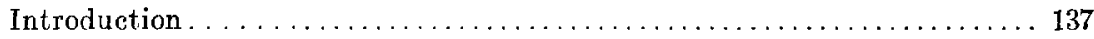

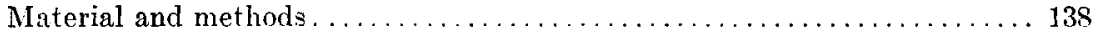

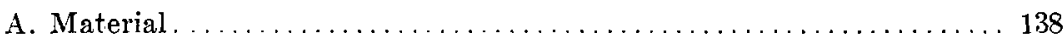

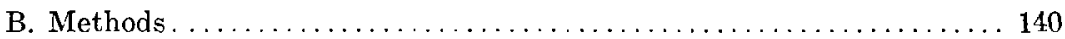

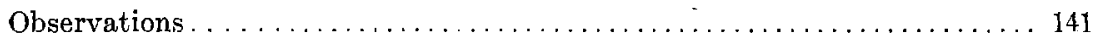

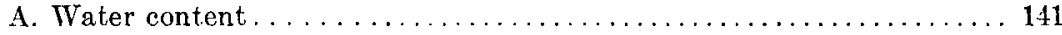

a. Relation between body weight and water content. . . . . . . 141

b. Specific differences . . . . . . . . . . . . . . . . . . . . . . . 143

c. Changes during the normal life cycle . . . . . . . . . . . . 144

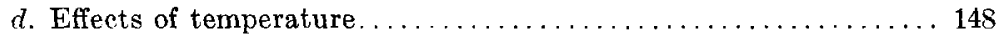

c. Effects of relative humidity of the air . . . . . . . . . . . 148

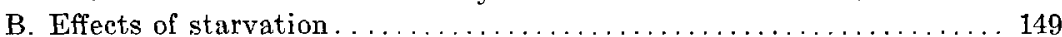

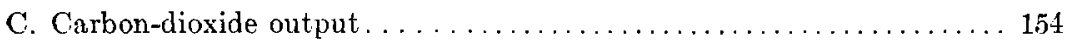

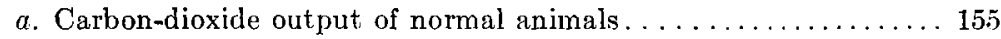

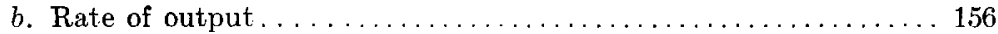

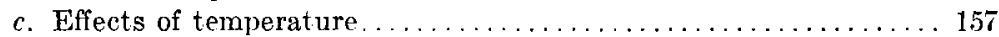

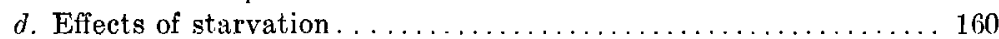

e. Effects of feeding starved animals . . . . . . . . . . . . 160

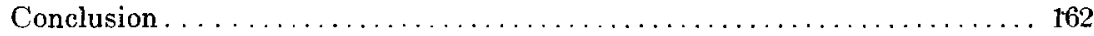

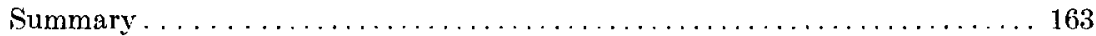

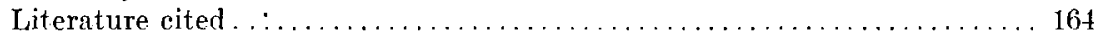

\section{INTRODUCTION}

In view of the fact that insects, which make up some fourfifths of the known species of the animal kingdom, have been so little investigated physiologically, it has seemed desirable to study intensively some of the physiological phenomena of a typical insect, the grasshopper, and also to see in how far they agree with results obtained for higher forms. Some points of 
special interest are: changes occurring with age, differences due to species and sex, the effects of starvation and hibernation, as well as problems dealing with the various phases of metabolism. Results of such nature obtained for higher forms have contributed much toward the advancement of various theories of growth, senescence, etc. (Child, 1; Mathews, 2; Minot, 3), as well as to our knowledge of changes in organisms which are closely related to age, sex, etc. (Hatai, 4).

The present investigation deals with such problems as the percentage of water during growth, starvation, and 'hibernation' in different species of grasshoppers, and also the rate of metabolism as indicated by determinations of the amounts of carbon dioxide given off by the animals.

\section{MATERIAL AND METHODS}

\section{A. Material}

Grasshoppers were used in all the following experiments. These animals have been found to be excellent material because of the ease with which they can be obtained, kept under usual laboratory conditions, and handled in experiments. They are sufficiently large to be used individually, and this is of great importance because most of the physiological work heretofore done on insects has been concerned with masses rather than with individual animals.

The following species were used: Melanoplus femur rubrum, Melanoplus differentialis, Dichromorpha viridis, and Chortophaga viridifasciata, and they will be discussed in the order given.

Melanoplus femur rubrum DeGeer, the red-legged locust, is perhaps the most common grasshopper found throughout the entire United States. Its general life-history is practically typical; eggs are laid in the late summer and early fall and remain over winter; nymphs hatch in early summer, and by the last of July and early part of August, in the vicinity of Philadelphia, adults are found. It occurs in rather large numbers throughout the entire summer. The average length of the body of adult 
males is $23.5 \mathrm{~mm}$., and of females, $24.5 \mathrm{~mm}$.; average weights are: adult males, 0.20 to 0.40 gram; females, 0.25 to 0.65 gram. Nymphs range in weight up to a maximum of 0.35 gram. ${ }^{1}$

Melanoplus differentialis Uhler, the largest grasshopper found in this vicinity, closely parallels Melanoplus $f$. rubrum in lifehistory. In length adult males measure $39 \mathrm{~mm}$, and females, $41 \mathrm{~mm}$. Adult males weigh 0.7 to 1.3 grams, and females, 1.3 to 2.8 grams.

Dichromorpha viridis scudder has a general life-cycle similar to the above-described species. However, it is not as active an animal and occurs in open wet places. Differences in size between adult males and females are marked. Adult males measure $18.75 \mathrm{~mm}$. and females, $27.0 \mathrm{~mm}$. In weight adult males range from 0.15 to 0.20 gram, and females, from 0.15 to 0.55 gram.

Chortophaga viridifasciata DeGeer is quite different in lifecycle from the above-mentioned species. Eggs are laid in late spring and early summer; these hatch in later summer and early fall; the nymphs live throughout the winter, and in spring grow rapidly, and become adults by early summer. Two-thirds of their active life, in contrast with other species, is spent as nymphs and approximately one-third as adults. Two well-marked varieties occur, a green form (virginaria Fab.) and a brown form (infuscata Harris). Most females are green and males brown, but some are found of each sex in either color, and as a matter of fact, when green animals are put at a constant temperature of $38^{\circ} \mathrm{C}$. they turn brown in a very short time. Adult males measure $25 \mathrm{~mm}$. and weigh 0.10 to 0.20 gram; females measure $30 \mathrm{~mm}$. and weigh 0.15 to 0.45 gram.

For further descriptions of the above species reference is made to standard text-books on entomology and to the works of Morse (6) and Lugger (5).

1 Average dimensions of animals used are taken from Lugger (5), while body weights have been determined by the author. 


\section{B. Methods}

The following general description of methods applies to all experiments and any further details will be given in describing individual cases.

All animals were caught in the vicinity of Philadelphia during the summer and fall of 1919-1920, brought into the laboratory, where they were kept in large screened insect cages, designated as stock cages. They remained in these cages for at least a day under the usual laboratory conditions, and were fed during this time on grass. Inasmuch as grasshoppers normally consume a great deal, those kept in the laboratory for a day ate large amounts of the grass, and upon examination the alimentary canal was found to be filled, thus insuring uniformity as to initial amounts of food. General laboratory conditions remained constant throughout the experiments, and any slight temperature changes, usually occurring at this particular season of the year, are noted in data following.

Animals were separately weighed in a small covered beaker on a rather delicate balance, determinations being made to four places of decimals. After weighing they were marked by gluing a small numbered tag on the pronotum, which mark could easily be removed and again attached, thus avoiding confusion in keeping accurate records of individuals. After initial weighing they were kept, in groups of five to ten, in small wire insect cages.

In determining water content, individuals were killed with chloroform, opened by a longitudinal slit through the abdomen, and then put in an oven at $95^{\circ}$ to $97^{\circ} \mathrm{C}$. and left there for a period of one week. This was found to be more than ample time for complete desiccation.

Carbon-dioxide determinations were made by the barium hydrate titration method of Lund ( 7$)$, using single animals, and each determination extending over a period of thirty minutes to one hour. In suspending individuals in the respiration bottle they were carefully tied around the prothorax by means of a fine silk thread. This was found to cause them little incon- 
venience if properly adjusted, and if it was kept sufficiently short, they did not move about to any appreciable extent but rested upon the sides of the bottle. Experiments in which the animal was confined in a small wire cage, just large enough to accommodate it and not allowing body movements, gave results quite similar to those in which the animal was suspended by the thread. In any such experiments, however, it is quite impossible to entirely eliminate movements by the individual, but by careful handling and manipulation they can be greatly lessened, and comparable, if not accurate, results obtained. In the following experiments emphasis is laid upon relative rather than upon absolute amounts of carbon dioxide given off.

Acknowledgment is made to Prof. C. E. McClung for the original suggestion of work on the physiology of the grasshopper, and to Prof. M. H. Jacobs I am deeply indebted for constant advice and criticism during the course of the work. To the members of the Zoological Department of the University of Pennsylvania I am also greatly indebted for generous help and criticisms.

\section{OBSERVATIONS}

\section{A. Water content}

The physiological importance of water to organisms is too well known to require special discussion. In recent years, many determinations of water content have been made on different organisms, and on the same organisms under different conditions, and the results have thrown much light on such questions of biological interest as the cause of certain tropic responses (Breitenbecher, 8), the nature of the process of senescence (Hatai, 4), the question of the influence of different foods (Babcock, 9), etc. Determinations of this sort have been made mostly on higher forms, and no such observations appear to be available for grasshoppers, which I have, therefore, studied rather extensively.

a. Relation between body weight and water content. Table 1 gives the body weights and water contents of 981 individuals, 
comprising nymphs and adults of Melanoplus f. rubrum and adults of Dichromorpha viridis and Melanoplus differentialis. It is evident from an examination of this table that considerable variation in the body weights for the different species exists. These can be explained by a consideration of the differences due to species, age, and random variations. It will be noted, for instance, that of the species studied, Melanoplus differentialis is by far the heaviest, reaching a maximum of 2.9 grams. Range in weight for Melanoplus f. rubrum is of interest, since weights for both nymphs and adults are given, and these show that as the animals become adults there is a progressive increase in body weight up to a maximum for the species. Males never reach the same maximum weights as females, and this is not due primarily to development of masses of eggs by the older females, since in nymphs this relation also holds. Consequently any comparison between males and females of the same weights will not necessarily be between those of the same age. Different conditions, such as food supply, development of reproductive elements, etc., modify the maximum weights of animals, causing some variation among individuals of the same age as shown for Melanoplus differentialis, where the animals are of approximately the same age and show rather large variations in body weights.

Closely related to these differences in body weights of the animals are the changes occurring in the percentages of water. With increasing body weight and age, a progressive diminution in the relative water content takes place, as shown especially by Melanoplus $f$. rubrum, where nymphs have an average maximum of 77.6 per cent and adults an average minimum of 72 per cent. That this diminution in water content is related to age, and not to body weight, is shown by a comparison of these results with those for Melanoplus differentialis, where the animals are of the same age, but differ in body weights, and have approximately the same percentage of water. A similar result has been found by Hatai (4), for the albino rat, in which the percentage of water during the life-span decreases from 87.2 per cent to 65.3 per cent and bears no relation to body weight, but depends primarily upon the age of the animal. It will also 
be noted that the average percentage of water for the adult males of Melanoplus f. rubrum tends to be slightly higher than that for the females, and that for Dichromorpha viridis the reverse relation is found.

\section{TABLE 1}

Showing the percentage of water in normal grasshoppers of different species. Figures in () giving the number of amimals used

\begin{tabular}{|c|c|c|c|c|c|c|c|c|}
\hline \multirow{3}{*}{$\begin{array}{c}\text { BODY } \\
\text { WEIGHT }\end{array}$} & \multicolumn{8}{|c|}{ PERCENTAGE OF WATER } \\
\hline & \multicolumn{2}{|c|}{$\begin{array}{l}\text { Melanophus } f \text {. } \\
\text { rubrum (nymphs) }\end{array}$} & \multicolumn{2}{|c|}{$\begin{array}{c}\text { Helanophus f, rubrum } \\
\text { (aclults) }\end{array}$} & \multicolumn{2}{|c|}{$\begin{array}{c}\text { Diehremorpha viridis } \\
\text { (adults) }\end{array}$} & \multicolumn{2}{|c|}{$\begin{array}{l}\text { Melanophus differ- } \\
\text { entialis (adults) }\end{array}$} \\
\hline & $0^{\pi}$ & $¥$ & $\sigma^{7}$ & Q & $\sigma^{7}$ & $q$ & $\sigma^{\pi}$ & q \\
\hline grams & & & & & & & & \\
\hline $0.10-0.15$ & $76.7(8)$ & $78.5(11)$ & & & $69.8(34)$ & $75.1(25)$ & & \\
\hline $0.15-0.20$ & $75.0(10)$ & $77.9(14)$ & $74.9(7)$ & & $64.9(15)$ & $74.3(15)$ & & \\
\hline $0.20-0.25$ & $74.8(13)$ & $74.1(15)$ & $74.2(19)$ & $76.0(25)$ & & $74.3(40)$ & & \\
\hline $0.25-0.30$ & & $73.9(10)$ & $73.6(32)$ & $7+.1(40)$ & & $73.3(42)$ & & \\
\hline $0.30-0.35$ & & $74.4(12)$ & $73.4(47)$ & $74.5(45)$ & & $71.8(50)$ & & \\
\hline $0.35-0.40$ & & & $73.9(19)$ & $72.5(23)$ & & $68.4(57)$ & & \\
\hline $0.40-0.45$ & & & & $70.8(12)$ & & $67.9(10)$ & & \\
\hline $0.45-0.50$ & & & & $73.1(14)$ & & $65.4(20)$ & & \\
\hline $0.50-0.55$ & & & & $71.2(27)$ & & $66.7(18)$ & & \\
\hline $0.55-0.60$ & & & & $71.1(13)$ & & & & \\
\hline $0.60-0.65$ & & & & $70.3(18)$ & & & & \\
\hline $0.90-1.10$ & & & & & & & $69.3(15)$ & \\
\hline $1.10-1.30$ & & & & & & & $69.6(11)$ & \\
\hline $1.30-1.50$ & & & & & & & & $69.7(10)$ \\
\hline $1.50-1.70$ & & & & & & & & $66.8(12)$ \\
\hline $1.70-1.90$ & & & & & & & & $71.0(25)$ \\
\hline $1.90-2.10$ & & & & & & & & $69.2(18)$ \\
\hline $2.10-2.30$ & & & & & & & & $69.0(10)$ \\
\hline $2.30-2.50$ & & & & & & & & $69.4(34)$ \\
\hline $2.50-2.70$ & & & & & & & & $69.9(27)$ \\
\hline $2.70-2.90$ & & & & & & & & $69.3(19)$ \\
\hline Average. & $5(41)$ & 75.7 & $74.0(124)$ & $72.6(217$ & & 70 & 69.4 & $68.0(155)$ \\
\hline
\end{tabular}

b. Specific differences. It will be noted from table 1 that the average percentage of water differs for the various species studied. For example, Melanoplus f. rubrum has an average water content of 74.4 per cent, Dichromorpha viridis 69 per cent, and Melanoplus differentialis 68.9 per cent. These averages (except 
those for Melanoplus differentialis) are based upon individuals taken during the entire summer and hence represent values for both young and old animals and can be considered as fair averages for the species. That such an average must be based upon the water contents of both young and old individuals is quite evident, since the preceding section shows that the percentage of water of an animal decreases with increasing age. It is of some interest to mention here that in another species of grasshopper, Chortophaga viridifasciata, the percentage of water during the winter months drops to a minimum of 65 per cent, while in the same animal when growing the water content is raised to 75 per cent. Since the percentage of water of an animal is thus dependent upon and so easily modified by external factors, such as temperature, moisture, etc., it is difficult to get data to show that definite species differences in water content exist. The present results for Melanoplus f. rubrum and Dichromorpha viridis, where the animals were under the same conditions, seem to show, however, that such a condition might occur. Babcock (9), in discussing 'metabolic water,' concludes that the water content of insects depends largely upon the nature of the food eaten, but does not show that those living upon the same foods may have different percentages of water.

c. Changes during the normal life-cycle. Some changes in the percentage of water during the life-cycle of grasshoppers have been shown in a preceding section. Chortophaga viridifasciata, however, because of its peculiar habit of living as a nymph during the winter and 'hibernating,' affords opportunity for further studying the various changes in water content which normally occur during such a period.

Table 2 gives results obtained for 565 specimens and shows that during this period the percentage of water falls from 72 per cent to 65 per cent. This minimum of 65 per cent is perhaps as far as desiccation can be carried without injurious results, and is a factor of some importance in the economy of the organism. Somewhat similar rhythmic variations in the water content of animals are shown for the frog by Donaldson (10), and for the potato-beetle by Breitenbecher (8). These 'hibernating' animals 
with low percentages of water, left at $38^{\circ} \mathrm{C}$. for a period of three weeks and fed grass, grow and become adults, and the various changes in the water content during this period are easily followed.

Table 3 selected from several such experiments shows that a growing animal has the maximum percentage of water (75 per cent), and that a progressive decrease in water content with age and increasing body weight, to a minimum of 65 per cent,

TABLE 2

Showing the percentage of water and solids of Chortophaga viridifasciata taken at different periods of the year

\begin{tabular}{|c|c|c|c|c|}
\hline \multirow{2}{*}{ DATE } & \multirow{2}{*}{ TEMPERATURE } & \multicolumn{2}{|c|}{ PERCENTAGE OF } & \multirow{2}{*}{$\begin{array}{l}\text { NUMBER OF } \\
\text { ANIMALS }\end{array}$} \\
\hline & & Water & Solids & \\
\hline & ${ }^{\circ} \mathrm{C}$. & & & \\
\hline October $10,1919 \ldots \ldots \ldots$ & $22-25$ & 72.0 & 28.0 & 50 \\
\hline October $11,1919 \ldots \ldots \ldots$ & $22-25$ & 72.0 & 28.0 & 35 \\
\hline November $4,1919 \ldots \ldots \ldots$ & 13.0 & 69.4 & 30.6 & 25 \\
\hline November 5,1919 . . . . . . . & 8.0 & 69.4 & 30.6 & 15 \\
\hline November $13,1919 \ldots \ldots \ldots$ & 10.0 & 66.5 & 33.5 & 17 \\
\hline November $14,1919 \ldots \ldots \ldots$ & 4.5 & 66.1 & 33.9 & 43 \\
\hline November 18, 1919. . . . . . . & 7.0 & 69.5 & 30.5 & 14 \\
\hline November $19,1919 \ldots \ldots \ldots$ & 7.5 & 67.3 & 32.7 & 60 \\
\hline November $23,1919 \ldots \ldots \ldots$ & 11.0 & 67.3 & 32.7 & 47 \\
\hline November $26,1919 \ldots \ldots \ldots$ & 9.0 & 65.7 & 34.3 & 62 \\
\hline December $3,1919 \ldots \ldots \ldots \ldots$ & 0 & 65.2 & 34.8 & 50 \\
\hline December $8,1919 \ldots \ldots \ldots$ & 5.0 & 65.2 & 34.8 & 34 \\
\hline December $16,1919 \ldots$ & 0 & 67.4 & 32.6 & 19 \\
\hline December $17,1919 \ldots \ldots \ldots$ & 0 & 66.5 & 33.5 & 38 \\
\hline December $22,1919 \ldots \ldots \ldots$ & 0 & 62.8 & 37.2 & 15 \\
\hline January $4,1920 \ldots \ldots \ldots \ldots$ & 0 & 65.0 & 35.0 & 41 \\
\hline
\end{tabular}

takes place. Figure 1 gives graphically and in more detail, similar results taken from many experiments which show the water content and weight relations of animals during the period from October, 1919, to January, 1920. The results of two experiments at different intervals, giving the effects of a constant temperature of $38^{\circ} \mathrm{C}$., are also indicated.

From this figure it is to be noted that during this four-month period, rather marked changes in the water content of animals take place, while body weights undergo only slight and gradual 
increases. With the approach of cold weather the animal begins gradually to lose water, and with sudden decrease in temperatures rather marked drops, to a minimum of 65 per cent,

TABLE :

Showing the changes in water content of Chortophaga vividifasciata during different stages of its life-cycle

\begin{tabular}{|c|c|c|c|}
\hline WEIGHT OF ANIMAL & BTAGE OF GROWTH & CONDITION & PER CENT OF WATER \\
\hline yrams & & & \\
\hline $0.059 \mathrm{~s}$ & Nymph & Growing & 74.9 \\
\hline 0.0648 & Nymph & Growing & 76.8 \\
\hline 0.0749 & Nymph & Growing & 73.2 \\
\hline 0.0800 & Nymph & Growing & 75.2 \\
\hline 0.0895 & Nymph & Growing & 77.6 \\
\hline 0.1100 & Nymph & Growing & 77.8 \\
\hline 0.1700 & Nymph & Growing & 73.8 \\
\hline 0.2498 & Nymph & Growing & 74.1 \\
\hline 0.0700 & Nymph & Hlbernating & 64.8 \\
\hline 0.0750 & Nymph & Hibernating & 60.6 \\
\hline 0.0750 & Nymph & Hibernating & 65.4 \\
\hline 0.0725 & Nymph & Hibernating & 65.6 \\
\hline 0.0848 & Nymph & Hibernating & 64.7 \\
\hline 0.0840 & Nymph & Hibernating & 66.7 \\
\hline 0.0885 & Nymph & Hibernating & 66.0 \\
\hline 0.1020 & Nymph & Hibernating & 65.7 \\
\hline 0.2780 & Adult & Growing & 76.5 \\
\hline 0.3850 & Adult & Growing & 73.4 \\
\hline 0.3715 & Adult & Growing & 75.3 \\
\hline 0.3150 & Adult & Growing & 74.7 \\
\hline 0.4130 & Adult & Growing & 73.4 \\
\hline 0.4230 & Adult & old & 67.0 \\
\hline 0.1350 & Adult & Old & 61.5 \\
\hline 0.2640 & Arlult & Old & 68.6 \\
\hline 0.3020 & Adult & OId & 69.3 \\
\hline 0.2480 & Adult & Old & 63.2 \\
\hline 0.3970 & Adult & Old & 61.6 \\
\hline 0.3630 & Adult & Old & 61.5 \\
\hline 0.4570 & Adult & Old & 64.9 \\
\hline
\end{tabular}

occur. The water content then remains at this minimum during the remainder of cold weather. Despite this preparation for the winter by a falling off in the percentage of water, the process seems one quite easily changed at any period by exposure to a 
higher temperature of $38^{\circ} \mathrm{C}$. The two experiments represented show results typical for many others obtained at different intervals during this four-month period. It will be noted that a marked and steady increase in body weight takes place, until at the end of approximately three weeks, the maximum for the species is attained. The percentage of water, on the other hand,

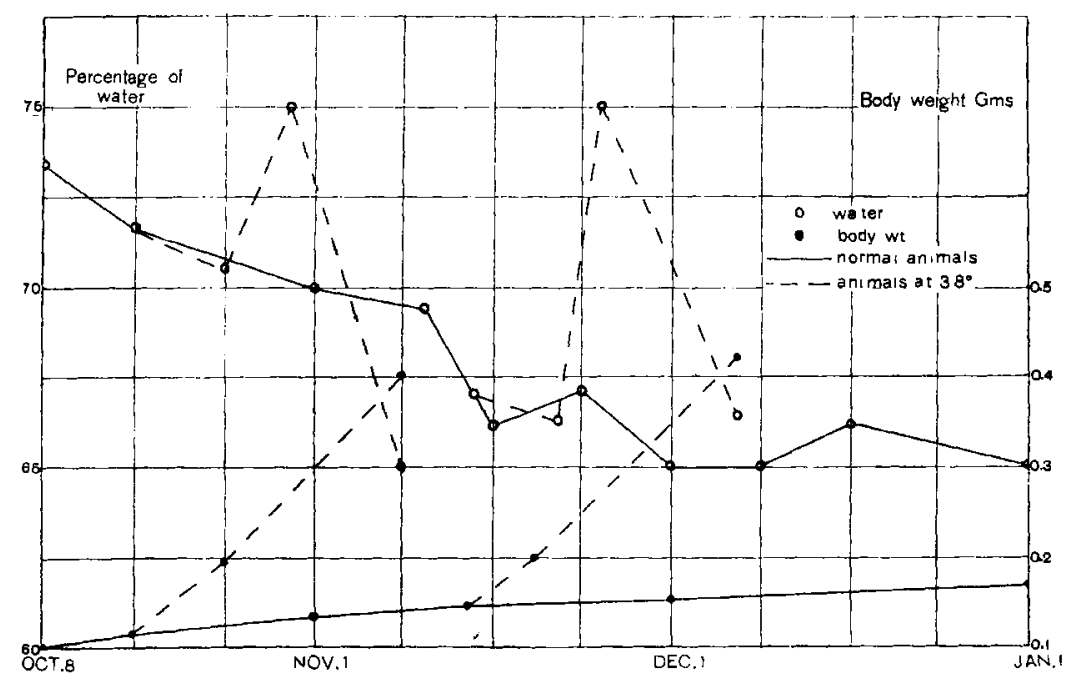

Fig. 1 Curves show the water content and weight relations of Chortophaga viridifasciata, during four months, from October 8,1919 , to January 1, 1920, out of doors, and also the effects of $38^{\circ} \mathrm{C}$. on these relations in 'hibernating' nymphs. Abscissas, time in weeks indicated. Ordinates, at the left, the percentage of water. Ordinates, at the right, body weight in grams. For further explanation see description in text.

undergoes rather striking and regular changes. A slight decrease, followed by a rapid increase to a maximum of 75 per cent and accompanied by active growth, and a correspondingly rapid decrease, closely connected with the later stage of the animals' life, occur. Such a result strikingly confirms conclusions arrived at in an earlier section in which such differences in water content were shown to be correlated with the age and not the body weight of an animal. 
d. Effects of temperature. As pointed out in the preceding section, raising the temperature to $38^{\circ} \mathrm{C}$. causes marked changes in the water content of 'hibernating' individuals. That such results can be obtained at other temperatures is shown from a series of experiments in which 'hibernating' nymphs were kept at $9^{\circ}, 23^{\circ}$, and $38^{\circ} \mathrm{C}$, respectively, for periods of three weeks and fed grass. Progressive increases in the percentage gains of water, body weight, and solids take place in all three series, being highest, however, at $38^{\circ}$; while with nothing to eat at these temperatures the animals die, thus showing that during the winter a real hibernation can hardly be supposed to take place, since it is generally understood that hibernating animals require no food other than that already stored in the body.

e. Effects of relative humidity of the air. 'Hibernating' nymphs were put into small cages covered with wire gauze and the cages were then put into, 1) sealed jars containing wet sand and filterpaper, 2) sealed jars with dry sand, and, 3) a desiccator containing calcium chloride, and kept at temperatures from $4^{\circ}$ to $38^{\circ} \mathrm{C}$. The animals were not in contact with the sand or wet filterpaper, and hence any increase in weight or water content cannot be attributed to imbibed water. Nothing was given the animals to eat. Table 4 shows the percentage loss in weight, water, and solids for ninety-five individuals treated in such a manner.

In general it is found that in the jars with dry sand and in the desiccators the animals lose weight and water, the losses being highest at $38^{\circ}$. Losses in water are relatively higher than those in body weight. In the jars with the wet sand, on the other hand, marked increases in body weight and water result. At $4^{\circ} \mathrm{C}$., however, a slight loss in weight (1.4 per cent) is noted, but an increase in water of 3.5 per cent takes place. Such a slight absorption of water at this lower temperature further shows how the organisms are protected during winter, preventing freezing and possible destruction. It is evident from these results that 'hibernating' nymphs are able to take up water directly from the surrounding medium. Breitenbecher (8) finds a similar condition in the potato-beetle. It is of interest to note, too, that old individuals with low percentages of water are unable 
to readjust their water relations when exposed to decreased temperatures. The animal's ability to regulate its moisture content seems to be connected with its ability to grow and withstand adverse conditions.

\section{TABLE 4}

Showing the percentage changes in weight, water, and solids in 'hibernating' Chortophaga viridifasciata when exposed to differences in relative humidit!

\begin{tabular}{|c|c|c|c|c|c|c|c|c|}
\hline \multirow{2}{*}{$\begin{array}{l}\text { INITIAL } \\
\text { WEIGHT }\end{array}$} & \multicolumn{4}{|c|}{ IERCENTAGE OF } & \multirow{2}{*}{ TIME } & \multirow{2}{*}{$\begin{array}{l}\text { NUMI- } \\
\text { BER OF } \\
\text { ANI- } \\
\text { MALS }\end{array}$} & \multirow{2}{*}{$\begin{array}{c}\text { TEM- } \\
\text { PERA- } \\
\text { TERE }\end{array}$} & \multirow{2}{*}{ REMARKS } \\
\hline & Water & $\begin{array}{l}\text { Change } \\
\text { in } \\
\text { wight }\end{array}$ & $\mid \begin{array}{c}\text { Change } \\
\text { in } \\
\text { water }\end{array}$ & $\begin{array}{c}\text { Change } \\
\text { in } \\
\text { solids }\end{array}$ & & & & \\
\hline orams & & & & & homiss & & ${ }^{\circ} \mathrm{C}$. & \\
\hline 0.4130 & 66.4 & -2.8 & -3.7 & -0.7 & 48 & 5 & 4 & In rage with samkl \\
\hline 0.4640 & 66.2 & -1.7 & -3.3 & +1.6 & 48 & 5 & 4 & In jar with sant \\
\hline 0.2950 & 60.5 & -10.4 & $=-23.9$ & +16.1 & $4 s$ & 5 & 15 & In jar with sand \\
\hline 0.3250 & 61.3 & -8.6 & -15.5 & +-5.0 & 24 & 5 & 23 & In jar with sand \\
\hline 0.3560 & 59.5 & -14.6 & $|-23.6|$ & +2.1 & 48 & 5 & 23 & In jar with sand \\
\hline 0.4150 & 60.5 & -21.9 & -41.6 & +7.1 & 24 & 5 & 35 & In jar with sand \\
\hline 0.4180 & 65.4 & -2.8 & -5.7 & +1.7 & 48 & 5 & 4 & In desiccator \\
\hline 0.3810 & 60.5 & -9.9 & -17.7 & +7.0 & 48 & 5 & 1.5 & In desiccator \\
\hline 0.3695 & 60.0 & -7.3 & $3 \mid-16.2$ & +10.5 & 24 & 5 & 23 & In desiccator \\
\hline 0.4315 & 60.1 & -11.7 & -23.5 & +2.4 & 48 & 5 & 23 & In desiccator \\
\hline 0.3730 & 59.9 & $-2+1$ & -34.0 & $\mid-4.4$ & 24 & 5 & 38 & In desiceator \\
\hline 0.5170 & 68.1 & -1.4 & +3.5 & $|-10.7|$ & 48 & 5 & 4 & In jar with wet sand \\
\hline 0.4230 & 64.8 & +3.5 & +0.5 & +9.5 & 48 & 5 & 15 & In jar with wet sand \\
\hline 0.3830 & 62.5 & +0.5 & +0.3 & +0.7 & 24 & 5 & 23 & In jar with wet sand \\
\hline 0.5810 & 71.6 & +14.3 & +22.6 & $|-2.3|$ & 48 & 5 & 23 & In jar with wet sand \\
\hline 0.3950 & 73.0 & +1.5 .5 & +28.0 & $-9.0 \mid$ & $2 t$ & 5 & 38 & In jar with wet sand \\
\hline $0.4345^{*}$ & 64.6 & -11.8 & -18.0 & -8.1 & 24 & 5 & 38 & In jar with wet sand \\
\hline $0.4660^{*}$ & 64.4 & -14.8 & $|-18.7|$ & -6.6 & 24 & 5 & 38 & In desiccator \\
\hline $0.4840^{*}$ & 61.9 & -3.7 & +1.9 & -15.6 & 24 & 5 & 38 & In jar with wet sand \\
\hline
\end{tabular}

$+=$ gain, $-=$ loss. $*=$ animals previously kept at $38^{\circ} \mathrm{C}$.

\section{B. Effects of starnation}

Before dealing with the direct effects of starvation on water content, solids, and body weight of these animals, some points of general interest deserve consideration, one of which is length of the starvation period. It is found that adults of Melanoplus f. rubrum endure complete starvation approximately 73 hours, while with water, but no food, they live as long as 144 hours 
with a loss of 30 to 35 per cent in body weight. On the other hand, Melanoplus differentialis, a larger species, survives complete starvation approximately 96 hours, and with water alone, about 172 hours with a loss in body weight of 20 to 25 per cent. Hibernating nymphs of Chortophaga with nothing to eat, at temperatures from $0^{\circ}$ to $9^{\circ} \mathrm{C}$., can survive only a little more than two weeks; at $23^{\circ}$ they live about one week, and at $38^{\circ}$ only three to four days. The maximum loss in weight up to death ranges from 20 to 25 per cent. Such a short survival period for the grasshopper is in marked contrast with that found for certain insects and related forms. Dufour (11) for example, kept bedbugs for a year without food, while Riley and Johannsen (12) cite examples where certain ticks were kept for over three years with nothing to eat.

The changes brought about by starvation in the body weight, water, and solids of the grasshopper are rather striking as the following results show. In all experiments adult animals were used and were weighed at twenty-four-hour intervals at the same time each day. The number for Melanoplus f. rubrum is 250, and for Melanoplus differentialis, 75 . Room temperature during the experiments remained at $22^{\circ}$ to $25^{\circ} \mathrm{C}$. Table 5 gives the percentage losses in body weight, water, and solids for differentsized individuals and for the two sexes of Melanoplus f. rubrum, during seventy-two hours of starvation, with and without water. Figure 2, taken from this table, shows the average losses in body weight and water, and figure 3 gives the average percentage loss in weight and also the average percentage loss in weight per day or the rate of loss, with water alone, for Melanoplus differentialis.

From an examination of these data we find that losses in body weight during starvation are marked, and that they increase progressively as starvation proceeds up to a maximum for the species. The rate of loss, indicated in figure 3 , is greatest, however, during the first forty-eight hours and diminishes subsequently up to the end of the experiment. Losses in water, as shown in figure 2 , are always relatively greater than those in weight, and maintain this same general relation throughout 


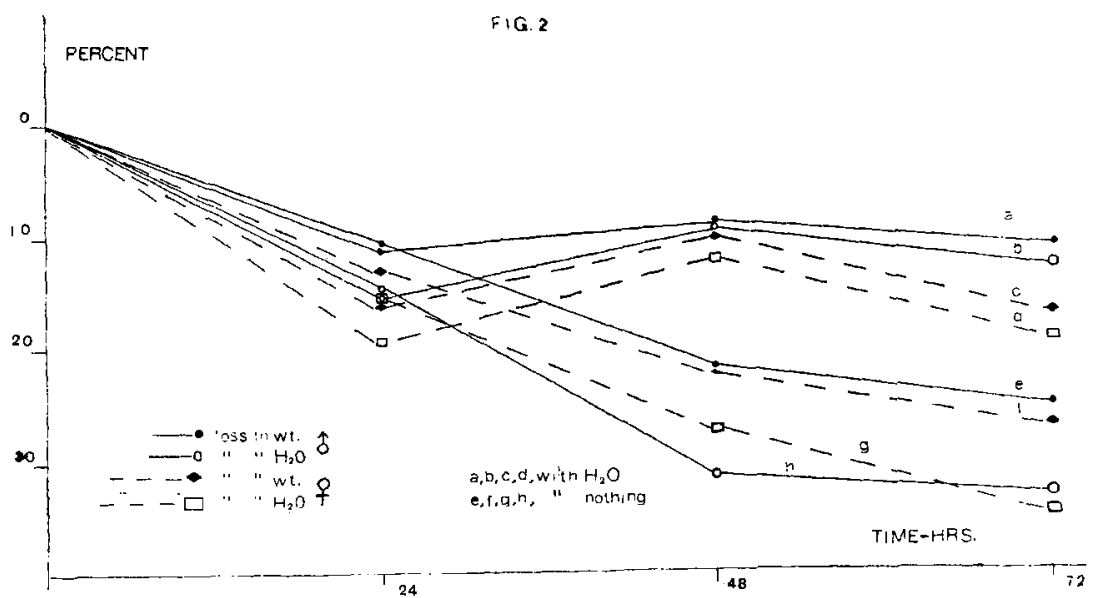

Fig. 2 Curves show the average percentage losses in body weight and water during starvation, with and without water, for both sexes of Melanoplus f. rubrum. Abscissas represent period of starvation in hours indicated by numbers. Ordinates represent percentage of losses occurring during starvation. See table 5 .

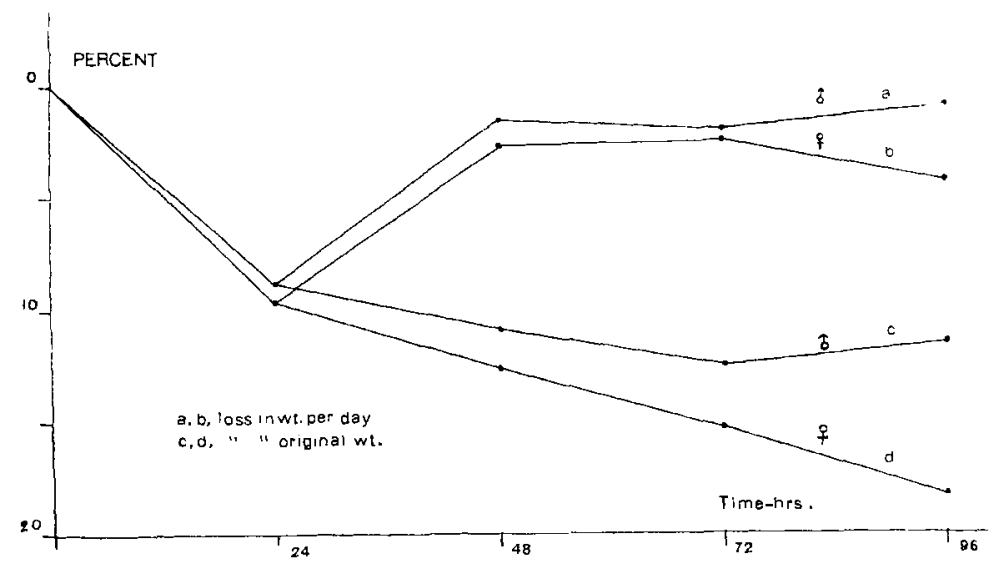

Fig. 3 Curves show the average percentage loss in body weight per day and the average percentage loss of original weight during starvation, with water, for both sexes of Melanoplus differentialis. Abscissas represent period of starvation in hours indicated by numbers. Ordinates represent percentage losses occurring during starvation. 
TABLE 5

Showing the water content and the percentage losses in body weight, water, and solids in Melanoplus $f$. rubrum during starvation. Top figures denoting

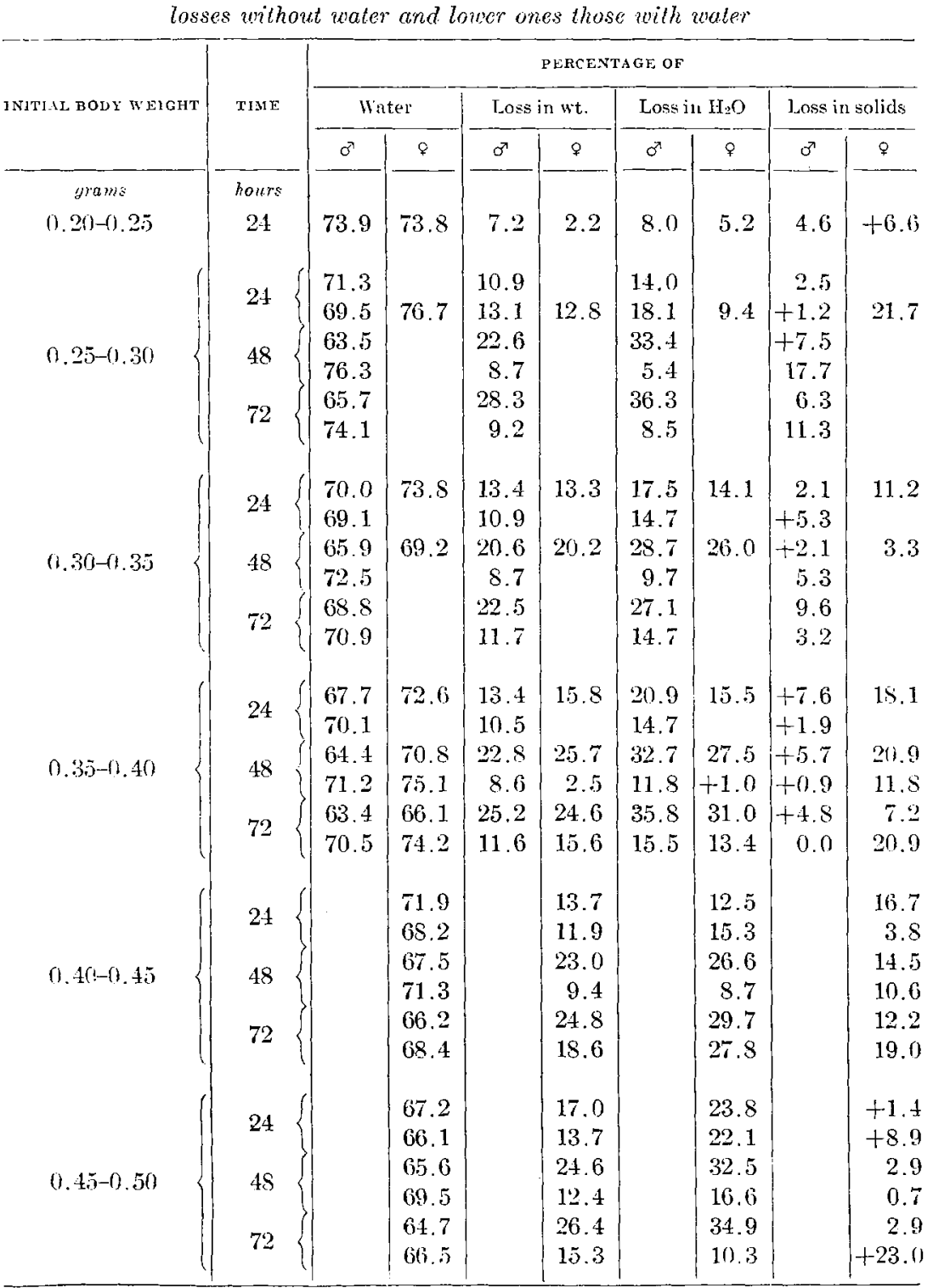


TABIE 5-Continued

\begin{tabular}{|c|c|c|c|c|c|c|c|c|c|}
\hline \multirow{3}{*}{ INITIAL BODY WEIGET } & \multirow{3}{*}{ TIME } & \multicolumn{8}{|c|}{ PERCENTAGE OF } \\
\hline & & \multicolumn{2}{|c|}{ Water } & \multicolumn{2}{|c|}{ Loss in wt. } & \multicolumn{2}{|c|}{ Loss in $\mathrm{H}_{2} \mathrm{O}$} & \multicolumn{2}{|c|}{ Lass in solids } \\
\hline & & $0^{\pi}$ & 운 10 & $\sigma^{\pi}$ & ㅇ & $0^{\pi}$ & q & or & q \\
\hline grams & hours & & & & & & & & \\
\hline \multirow{6}{*}{$0.50-0.55$} & 24 & & 66.8 & & 13.3 & & 18.6 & & 0.0 \\
\hline & & & 67.4 & & 18.8 & & 23.2 & & 7.5 \\
\hline & 48 & & 64.6 & & 20.7 & & 28.0 & & 2.5 \\
\hline & To & & 70.4 & & 15.6 & & 16.5 & & 13.2 \\
\hline & 72 & & 61.5 & & 33.9 & & 42.8 & & 11.3 \\
\hline & 84 & & 71.1 & & 18.0 & & 18.1 & & 17.7 \\
\hline \multirow{6}{*}{$0.55-0.60$} & $?$ & & 66.0 & & 13.9 & & 20.1 & & +1.7 \\
\hline & 24 & & 67.6 & & 17.9 & & 22.0 & & 7.3 \\
\hline & 48 & & 64.7 & & 18.2 & & 25.5 & & 0.0 \\
\hline & $4 \delta$ & & 68.2 & & 11.8 & & 15.4 & & 2.8 \\
\hline & 72 & & 63.5 & & 26.9 & & 34.6 & & 7.5 \\
\hline & & & 65.8 & & 17.0 & & 23.1 & & 1.7 \\
\hline \multirow{6}{*}{$0.60-0.65$} & & & 69.4 & & 15.6 & & 16.6 & & 12.9 \\
\hline & 24 & & 66.7 & & 21.2 & & 25.1 & & 11.9 \\
\hline & 48 & & 65.9 & & 22.7 & & 27.5 & & 11.3 \\
\hline & 19 & & 68.1 & & 9.6 & & 12.4 & & 2.5 \\
\hline & 72 & & 64.5 & & 25.6 & & 31.7 & & 10.8 \\
\hline & & & 66.4 & & 19.7 & & 24.0 & & 9.3 \\
\hline
\end{tabular}

starvation. Losses in solids, however, are invariably lower than those in body weight and water. This shows that starvation in the grasshopper results in a rapid loss in water which has a decidedly quick and fatal effect. In striking contrast to such a condition, Hatai (13), with medusae, and Morgulis (14), with salamanders, find that during starvation the water content is increased rather than decreased, but it must be remembered that in these cases we are dealing with aquatic forms. Table 5, arranged according to body weight, shows that considerable variation in the losses for different-sized individuals exists, but that after the first twenty-four hours of starvation, larger animals tend to suffer the greater relative losses. This is perhaps due to the fact that the lighter individuals are still growing, and as pointed out by Donaldson (15) in experiments with rats, the loss of water in the nervous system of underfed individuals is 
decidedly less for growing animals, and in growth such losses are markedly more fatal than when growth has ceased. It is also of interest to note that the average losses in body weight and water for males are lower than those for females.

The general effects of starvation, with and without water, are more graphically shown in figure 2 , where some of the data from table 5 are represented in the form of curves. It is quite evident from these that grasshoppers must normally require water, and that any condition which deprives them of it results in marked losses to the animal, which rapidly become fatal. No results on 'metabolic water' (Babcock, 9) are available, but it appears that in the grasshopper there is present little of the power shown by clothes moths, etc., of maintaining the proper degree of moisture in the body tissues from water resulting from the oxidation of the organic matter comprising the food and tissues of the animal.

\section{Carbon-dioxide output}

The respiratory exchange of animals is of physiological significance, since it gives quantitative evidence of the metabolic processes taking place in the organism. Measurements are made either of the oxygen consumption or the carbon-dioxide output, and at present methods for the detection of the latter quantity have been greatly improved and are especially favorable for work on lower forms, such as insects. The factor of greatest importance in such determinations, however, is the functional activity of the animal. In the organism as a whole, functional activity can be reduced only to a minimum, and in those animals, like insects, where narcotization is impossible, only approximations to this can be obtained.

From the results of various investigators, it is of interest to note that the respiratory rates for insects are considerably higher than those for other animals. For example, Vernon (16), finds that a cockroach, weighing 0.0007 kilogram, gives off 0.470 gram of carbon dioxide per kilogram per hour, while a frog, weighing 0.004 kilogram, gives off only 0.140 gram. Smaller and younger individuals of different species tend to have the 
higher respiratory rates. It is of importance, however, to mention here that most of the work heretofore done on insects has been concerned with masses rather than with individuals, and that little consideration has been given to results obtained for different species of the same general group, for different sexes, and for animals of different ages. The present discussion deals with the carbon-dioxide output of individual animals of different

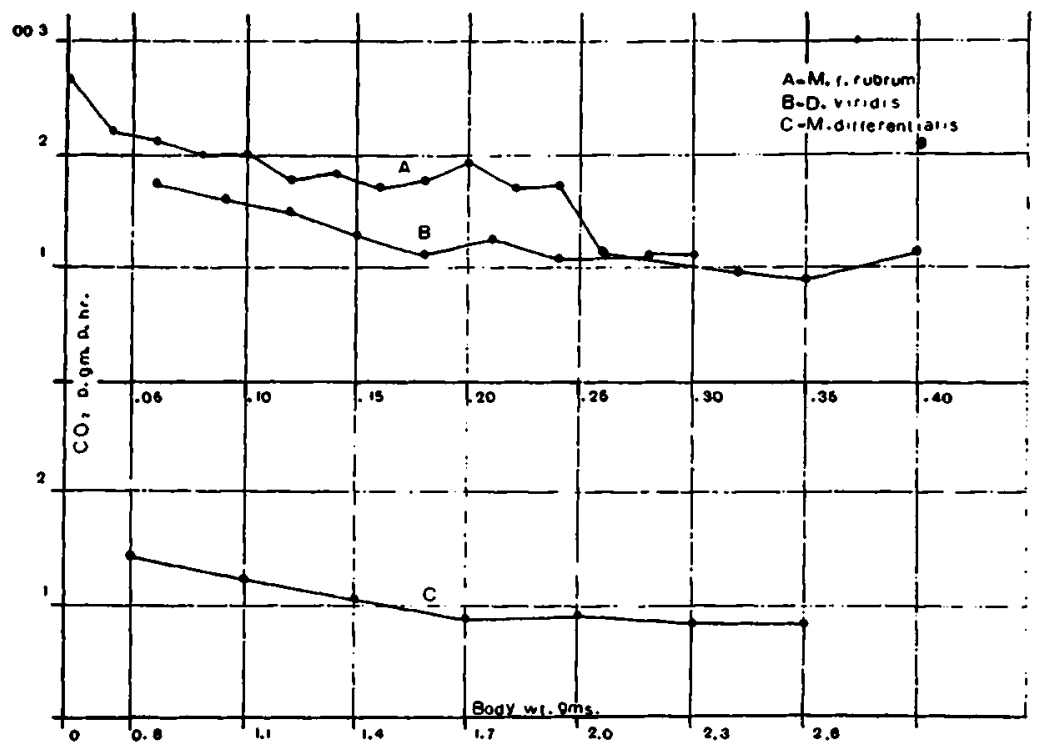

Fig. 4 Curves show the rate of $\mathrm{CO}_{2}$ output per gram per hour for nymphs of Melanoplus f. rubrum and Dichromorpha viridis and for adults of Melanoplus differentialis. Abscissas represent body weights in grams. Ordinates represent rates of $\mathrm{CO}_{2}$ output in grams $\mathrm{CO}_{2}$ per gran total body weight per hour, for the three species. For further explanation see text.

species, different ages, and of different sexes, under normal as well as experimental conditions. The following species of grasshoppers were studied: nymphs of Melanoplus f. rubrum and Dichromorpha viridis and adults of Melanoplus differentialis.

a. Carbon-dioxide output of normal animals. The number of individuals studied is, for nymphs of Melanoplus f. rubrum, 350; for nymphs of Dichromorpha viridis 300, and for adults of Melanoplus differentialis, 85. Figure 4 shows the average rates of carbon-dioxide output per gram per hour for these animals. 
An examination of this figure shows several interesting facts, the most striking of which is that a difference in rate of $\mathrm{CO}_{2}$ output is noted between the three species. That such a difference is not due to body weight is shown by a comparison of the respiratory rates of nymphs of Melanoplus $f$. rubrum and Dichromorpha viridis, which are of approximately the same weights. The most plausible explanation of this fact seems to be that this difference corresponds closely with the mode of life of the two species, Melanoplus f. rubrum being a very active animal, while Dichromorpha viridis is a relatively sluggish one. A point of further interest is that the rate of $\mathrm{CO}_{2}$ output is higher for lighter animals and decreases progressively as the animals increase in body weight. As it has already been pointed out that differences in body weight, especially in nymphs, are closely correlated with differences in age, we are led to assume that younger individuals have the higher rate of respiratory output. Like results are also found for other species. Since differences in body weight between males and females exist, the question naturally follows as to whether similar differences in the rate of $\mathrm{CO}_{2}$ output are found. Figure 6 shows that males tend to have the higher rate. The animals of the two sexes, in this case, are of approximately the same age, and differences in weight, as shown in a previous section, are due mostly to eggs in the female. Whether any fundamental difference in rate of respiratory exchange exists between the two sexes is somewhat doubtful, but such differences are reported for other animals, including man (Benedict and Emmes, 1\%).

b. Rate of output. Much evidence has been accumulated concerning higher forms and man to show that smaller individuals have a greater respiratory exchange per unit of weight than larger ones, and that respiratory exchange is proportional to the area of the surface of the body (Rubner, 18). For lower forms few such observations exist, Child (19), and Allen (20), for example, with Planaria, find that respiratory exchange decreases as the size of the worm increases, but give no calculations showing any possible surface relations. Krogh (21), in summarizing work done on lower forms, finds that results are conflicting, and 
concludes that no reason exists for assuming a surface relation to hold.

As already pointed out for the grasshopper, smaller individuals have per unit of weight a greater $\mathrm{CO}_{2}$ output than larger ones. And since the area of the surface of an animal is usually estimated from the body weight by means of the formula of Meeh (22), based on the law that surfaces of similar solids are proportional to the two-thirds power of volume, it is of some interest to see in how far the rate of $\mathrm{CO}_{2}$ output of the grasshopper can be thus expressed. In the following table are given a few examples of the ratio of $\mathrm{CO}_{2}$ output to body weight and to the two-thirds power of the weight, respectively.

\begin{tabular}{c|c|c}
\hline WEIOET OF ANIMAL & CO2 ACCORDING TO BODY WEIGHT & $\begin{array}{c}\text { CO ACCORDING TO THE } \\
\text { TWO-THIRDG POWER OF THE } \\
\text { BODY WEIGTT }\end{array}$ \\
\hline grams & 0.001000 & \\
2.16 & 0.001037 & 0.001290 \\
1.35 & 0.001174 & 0.001204 \\
1.11 & 0.001186 & 0.001224 \\
1.08 & 0.001215 & 0.001226 \\
1.05 & 0.001219 & 0.001236 \\
1.01 & 0.001263 & 0.001232 \\
1.01 & 0.001310 & 0.001276 \\
0.94 & & 0.001282 \\
\hline
\end{tabular}

It is evident that the more constant values are obtained by using the two-thirds power of the weight, and so far as the results here reported are concerned, the conclusion might reasonably be drawn, that the surface law holds for grasshoppers as well as for mammals. But in view of the complex nature of the problem, more extensive data will be necessary before this relation can be considered as definitely established.

c. Effects of temperature. The influence of temperature on the respiratory exchange is a somewhat disputed question because comparatively few observations are made under standard conditions. Krogh (21), however, in summarizing the work of various investigators, points out that different animals respond in different ways, but in general, with cold-blooded forms, increased temperatures cause increased respiratory rates, while 
with warm-blooded animals, the reverse is the case. 'The effects of temperature on the respiratory exchange of insects are especially marked and in general agree with results for other coldblooded forms. But since most of these results are based upon masses rather than individuals, it has seemed desirable to show the effects of temperature upon the respiratory exchange of individual animals. Three hundred and fifty nymphs of Melanoplus f. rubrum and three hundred of Dichromorpha viridis were

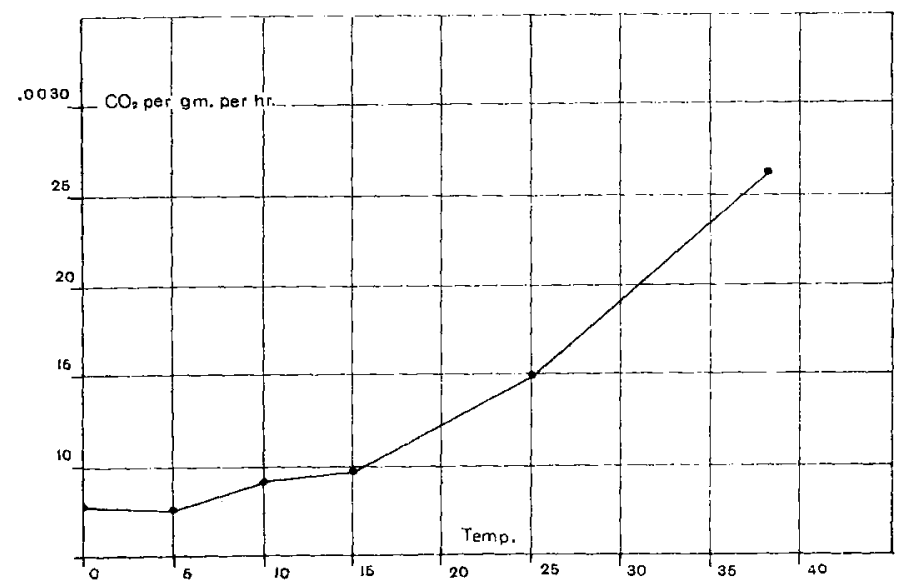

Fig. $\vec{b}$ Showing effects of various temperatures on the $\mathrm{CO}_{2}$ output of nymphs of Melanoplus f. rubrum and Dichromorpha viridis. Abscissas represent temperutures in degrees centigrade as indicated by the numbers. Ordinates represent rate of $\mathrm{CO}_{2}$ output in grams $\mathrm{CO}_{2}$ per gram total body weight per hour. For further rxplanation see text.

used. Figure 5, plotted from results, shows the average rate of $\mathrm{CO}_{2}$ output at various temperatures, ranging from $0^{\circ}$ to $38^{\circ} \mathrm{C}$.

Examination of this figure shows that in general grasshoppers respond to temperature changes as do other cold-blooded forms; that is, increased temperatures cause increased respiratory rates. At $38^{\circ}$ the rate of $\mathrm{CO}_{2}$ output is highest and in the interval from $0^{\circ}$ to $15^{\circ}$ it is nearly constant. This deviation from a regular increase from $0^{\circ}$ to $15^{\circ}$ is difficult to explain and perhaps is due to the imperfect control over conditions, such as body movements, etc. However, careful observation during the course 
of the experiments seemed to show no appreciable differences in body movements at the various temperatures. It is interesting to note to what extent these variations in respiratory rates are directly influenced by the different temperatures, and if a constant temperature coefficient, similar to that for other biological processes and chemical reactions, exists. As is well known, temperature influences on the velocity of certain chemical reactions can be satisfactorily expressed by the rule of van't Hoff, that for an increase in temperature of $10^{\circ} \mathrm{C}$., the rate is approximately doubled or trebled, i.e., there is a constant ratio, $Q_{10}$, of 3-2 for the rates at temperatures separated by an interval of $10^{\circ} \mathrm{C}$. Applied to the present results, $Q_{10}$, varies considerably, increasing with increasing temperatures, and is highest at $15^{\circ}$ to $25^{\circ}(1.5)$, and lowest at $0^{\circ}$ to $10^{\circ}(1.1)$. These figures, it will be noted, are somewhat lower than values obtained for chemical reactions. Values obtained for other biological processes are varied as the following examples show. Krogh (21); in experiments on the effects of temperature on the respiratory exchange of the chrysalids of the meal-worm, finds that $\mathrm{Q}_{10}$ for temperatures from $10^{\circ}$ to $30^{\circ} \mathrm{C}$., varies from 5.7 to 2.0 , being highest for lower temperatures. Respiration in seedlings from $0^{\circ}$ to $40^{\circ} \mathrm{C}$. has a value for $Q_{10}$ of $3-2$, (Clausen, 23) and in a leaf $2.4-1.8$, (C. L. Matthaei, 2/4). Here, too, the values for $Q_{10}$ are highest at lower temperatures and decrease as the temperature increases.

There is no fundamental reason why the respiratory exchange of an animal should follow the rule of van't Hoff; since we are dealing, not with a single chemical reaction, but rather with a group of reactions, most complex in nature. Why the temperature coefficient for the respiratory exchange of the grasshopper should be so much lower than that found for other forms is difficult to explain. Two plausible explanations suggest themselves, however. First, grasshoppers may possess some nervous regulatory mechanism by which their respiratory exchange is controlled and, secondly, the imperfect control over the animals during the experiments might account for such results. No such nervous mechanism is known to exist in insect, and if these results were due entirely to imperfect control over the animals, 
we should at least expect to find a much greater temperature coefficient for the higher temperatures, since the animals would then be most active. Much further investigation is necessary, however, before any satisfactory conclusions can be drawn.

d. Effects of starvation. Adult Melanoplus differentialis were starved, with water, for 96 to 120 hours and the rates of $\mathrm{CO}_{2}$ output measured during this period. Some eighty-five specimens were individually studied and results given are taken from selected cases showing typical conditions. Table 6 gives the actual amounts of $\mathrm{CO}_{2}$ given off and also the rate per gram per hour for males and females of different weights.

An examination of this table shows that the actual amount of $\mathrm{CO}_{2}$ given off by an animal decreases during successive periods of starvation. For example, the male weighing 1.0798 grams, at the start gave off 0.000704 gram of $\mathrm{CO}_{2}$, and at the end of 120 hours of starvation, only 0.00033 gram, a decrease of over one-half of the original amount. Since we already know that a loss in weight takes place during starvation, it is of interest to find that a decrease in the rate of $\mathrm{CO}_{2}$ output also occurs. During the early period of starvation this decrease tends to be rather slight and gradual, but at approximately forty-eight to seventy-two hours marked drops are noted. This decided decrease is doubtless due to the fact that at this time all residual food in the intestine has been utilized and body reserves alone are being used. Figure 6 shows that males have the higher rate of $\mathrm{CO}_{2}$ output and that these decreases are more marked for them. This is perhaps closely related to the difference in size between the animals of the two sexes. It is evident, then, from these results, that in grasshoppers as in other cold-blooded animals, frog (Hill, 25), Planaria (Hyman, 26; Child, 19; Allen, 20), $\mathrm{CO}_{2}$ output decreases during starvation-at first rather rapidly and later reaching a practically constant level up to the time of death.

e. Effects of feeding starved animals. It is a well-known fact that in higher forms, including man, ingestion of food after starvation results in an increased rate of metabolism. Recently Lund (27) has found similar results for Paramecium. Various 
experiments with starved grasshoppers also show striking results. Figure 6, taken from typical cases, shows the effect of feeding animals sprouted oats after periods of starvation, varying from 48 to 120 hours.

It is evident, from figure 6 , that feeding increases the $\mathrm{CO}_{2}$ output of starved animals. Some variations in extent of response

\section{TABLE 6}

Showing the actual $\mathrm{CO}_{2}$ per one-half hour and the rate of $\mathrm{CO}_{2}$ output per gram per hour, during sturvation, for Melanoplus differentialis. Figures in italics representing $\mathrm{CO}_{2}$ in grans per gram tolal body weight per hour

\begin{tabular}{|c|c|c|c|c|c|c|c|c|}
\hline \multirow{2}{*}{$\begin{array}{l}\text { WEIGHT } \\
\text { OF } \\
\text { ANIMAI }\end{array}$} & \multirow{2}{*}{$\mathrm{SEX}$} & \multirow{2}{*}{ NORMAL } & \multicolumn{5}{|c|}{ STARVATION PERIOD } & \multirow{2}{*}{$\begin{array}{l}\text { TEM- } \\
\text { PERA- } \\
\text { TURE }\end{array}$} \\
\hline & & & 24 hours & 48 hours & 72 hours & 96 hours & 120 hours & \\
\hline brams & & & & & & & & \\
\hline 2.0500 & 우 & $\left\{\begin{array}{l}0.0006270 \\
0.0006116\end{array}\right.$ & $\left\{\begin{array}{l}0.0004840 \\
0.0005792\end{array}\right.$ & $\left|\begin{array}{l}0.0005940 \\
0.000617\end{array}\right|$ & $\begin{array}{l}0.0006600 \\
0.0006760\end{array}$ & $\left\{\begin{array}{l}0.0004510 \\
0.0004832\end{array}\right.$ & $\left\{\begin{array}{l}0.0004400 \\
0.0004730\end{array}\right.$ & 21 \\
\hline 1.0100 & $\sigma^{\pi}$ & $\left\{\begin{array}{l}0.006380 \\
0.0012360\end{array}\right.$ & 0.0005390 & 0.0007260 & $\begin{array}{l}0.0004620 \\
0.0009150\end{array}$ & $\left\{\begin{array}{l}0.0005830 \\
0.0011770\end{array}\right.$ & $\left\{\begin{array}{l}0.0005940 \\
0.0012310\end{array}\right.$ & 21 \\
\hline 1.8995 & 甲 & $\left\{\begin{array}{l}0.00008030 \\
0.0008454\end{array}\right.$ & $\begin{array}{l}0.0007590 \\
0.0008116\end{array}$ & $\left\{\begin{array}{l}0.0008140 \\
0.0009170\end{array}\right.$ & 0.0006160 & $\left\{\begin{array}{l}0.0005610 \\
0.0007216\end{array}\right.$ & $\begin{array}{l}0.0007040 \\
0.0007645\end{array}$ & 21 \\
\hline 0.8995 & $0^{7}$ & $\left\{\begin{array}{l}0.0007810 \\
0.0017360\end{array}\right.$ & 0.0006160 & $\mid \begin{array}{l}0.0005170 \\
0.0012840\end{array}$ & $\mid \begin{array}{l}0.0004840 \\
0.0012100\end{array}$ & $\begin{array}{l}0.0003366 \\
0.0008634\end{array}$ & & 22 \\
\hline 0.7795 & $\sigma^{x}$ & $\left\{\begin{array}{l}0.0006490 \\
0.0016650\end{array}\right.$ & $\begin{array}{l}0.0004840 \\
0.0014560\end{array}$ & $\left\{\begin{array}{l}0.0004840 \\
0.0013450\end{array}\right.$ & $\begin{array}{l}0.0004180 \\
0.0012030\end{array}$ & $\begin{array}{l}0.0002486 \\
0.0007106\end{array}$ & & 22 \\
\hline 2.1200 & q & $\left\{\begin{array}{l}0.0010340 \\
0.0009754\end{array}\right.$ & 0.0010070 & 0.0009790 & $\begin{array}{l}0.0007040 \\
0.000 \% 650\end{array}$ & $\begin{array}{l}0.0005940 \\
0.0006562\end{array}$ & $\left\{\begin{array}{l}0.0006270 \\
0.0007130\end{array}\right.$ & 22 \\
\hline 0.9615 & $\sigma^{7}$ & $\left\{\begin{array}{l}0.0006600 \\
0.0013680\end{array}\right.$ & $\begin{array}{l}0.0006600 \\
0.0016290\end{array}$ & $\mid \begin{array}{l}0.0006116 \\
0.0015720\end{array}$ & $\begin{array}{l}0.0004620 \\
0.0011840\end{array}$ & $\left(\begin{array}{l}0.0003740 \\
0.0009906\end{array}\right.$ & & 23 \\
\hline 1.9100 & 웅 & $\left\{\begin{array}{l}0.0013970 \\
0.001 \div 620\end{array}\right.$ & $\left\{\begin{array}{l}0.0010010 \\
0.0013030\end{array}\right.$ & $\mid \begin{array}{l}0.0008860 \\
0.0011220\end{array}$ & 0.0006600 & $\begin{array}{l}0.0003300 \\
0.0006970\end{array}$ & $\begin{array}{l}0.0003300 \\
0.0006740\end{array}$ & 23 \\
\hline 1.0798 & $\sigma^{\gamma}$ & $\left\{\begin{array}{l}0.0007040 \\
0.0013090\end{array}\right.$ & 0.0007920 & $\begin{array}{l}0.0007100 \\
0.0013930\end{array}$ & 0.0006600 & $\left\{\begin{array}{l}0.0005280 \\
0.0006004\end{array}\right.$ & & 21 \\
\hline 1.2148 & $\sigma^{x}$ & $\left\{\begin{array}{l}0.00006160 \\
0.0010140\end{array}\right.$ & $\begin{array}{l}0.0006380 \\
0.0011650\end{array}$ & $\begin{array}{l}0.0008200 \\
0.0016750\end{array}$ & $\left\{\begin{array}{l}0.0006820 \\
0.0013640\end{array}\right.$ & 0.0005500 & 0.0005280 & 21 \\
\hline
\end{tabular}


occur, but generally it has been found that the rate of output is approximately doubled three hours after feeding. The effects of a single feeding, however, last but a short time, depending upon the amount of food eaten. No detailed study of the effects of different amounts of different foods has been made, but an animal starved for forty-eight or more hours and then fed always shows an increased output. This increase gradually rises as the weight increases until the animal gains its normal weight relations. Such results, showing that starved grasshoppers respond to ingestion of food by increased production of $\mathrm{CO}_{2}$, agree with those for other forms, and especially with those of Allen (20) for Planaria.

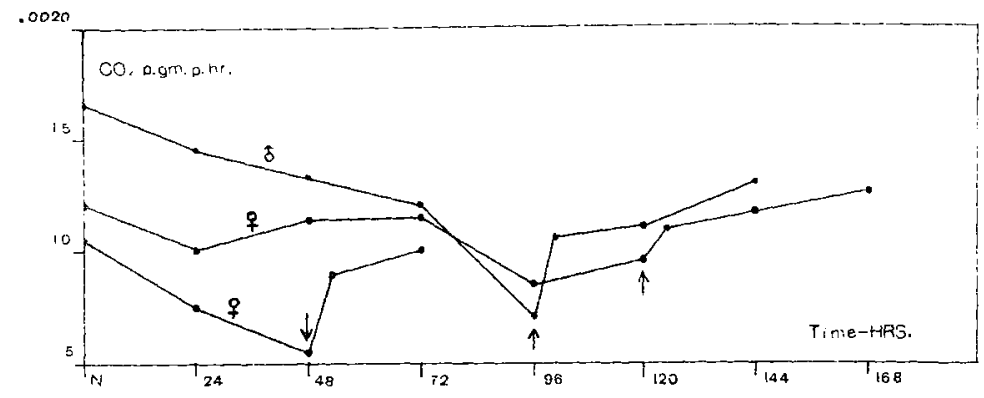

Fig. 6 Curves show decrease in $\mathrm{CO}_{2}$ output by Melanoplus differentialis during starvation and increase after feeding. Abscissas represent time in hours indicated by numbers. Ordinates represent rate of $\mathrm{CO}_{2}$ output in grams $\mathrm{CO}_{2}$ per gram total body weight per hour. Time at which feeding was begun indicated by arrow. See text for further description.

\section{CONCLUSION}

The results of the present study, as presented above, seem to indicate the extent to which comparisons between some of the physiological phenomena of insects and mammals can be made. It is found that the percentage of water an animal contains is characteristic for the particular species, and that it decreases with age and increasing body weight. When exposed to low temperatures, the animals respond by a decrease in water content and are thus prevented from freezing and possible destruction. 
Starvation results in marked and rapid losses in body weight, water, and solids, but the greatest and quickest loss seems to be of water. Closely correlated with these losses is a decrease in the rate of $\mathrm{CO}_{2}$ output. Various species of animals seem to have different rates of respiratory exchange, but all show a higher rate for the younger individuals. Increased temperatures cause increased rates of $\mathrm{CO}_{2}$ output, while lower temperatures seem to have the reverse effect. Ingestion of food by starved animals greatly increases the rate of $\mathrm{CO}_{2}$ production. By a comparison of these data with those found for mammals, striking similarities are found to exist, and these would seem to indicate that the problem of insect physiology, although at first seemingly unrelated to that of mammals, has, in fact, many points in common with it.

\section{SUMMARY}

1. The percentage of water an animal (grasshopper) contains decreases with age and increasing body weight, up to a minimum for the species.

2. Different species of the same general group, living lipon similar foods, may have different percentages of water.

3. During the active life-cycle of Chortophaga viridifasciata, the water content falls to a minimum during 'hibernation,' rises again to a maximum when 'hibernation' is broken up, and then again falls to a minimum as the animal grows old. These changes seem to be due to the effects of temperature and advancing age.

4. Water and temperature are the controlling factors in Chortophaga's emergence from 'hibernation.'

5. Different species of grasshoppers studied, under similar conditions, survive starvation for different periods of time, e.g., Melanoplus differentialis, 172 hours; Melanoplus f. rubrum, 144 hours, and Chortophaga viridifasciata, 170 hours.

6. Starvation results in losses of body weight, water, and solids, the greatest relative loss being of water. With water alone, losses are lower than with nothing.

7. Larger individuals tend to lose relatively greater amounts during starvation. 
8. Rates of $\mathrm{CO}_{2}$ output differ for the different species of animals studied.

9. Lighter and younger animals have the higher rates of $\mathrm{CO}_{2}$ output, and the possible relation of a surface law holding for grasshoppers is indicated.

10. Temperature influences on the $\mathrm{CO}_{2}$ production are rather marked, higher temperatures cause increased rates of $\mathrm{CO}_{2}$ output and lower temperatures tend to have the reverse effect. However, the temperature coefficients for these different temperatures are variable and are also considerably lower than those found for other biological processes.

11. Starvation causes a decrease in the rate of $\mathrm{CO}_{2}$ output.

12. Feeding starved individuals results in an increase in the rate of $\mathrm{CO}_{2}$ output.

\section{LITERATURE CITED}

ChILd, C. 1915 Senescence and rejuvenescence. Chicago.

Mathews 1916 Physiological chemistry, 2nd ed. New York.

Minot 1908 Age, growth and death. New York.

HataI 1917 Am. Jour. Anat., vol. 21, p. 23.

LUGGER 1897 Orthoptera of Minnesota.

Monse 1896-97 Psyche, vols. 7 and 8.

LUND 1918 Biological Bulletin, vol. 34, p. 105.

Breitenkecher 1918 Carn. Inst. Pub., no. 263

BAвсоск 1912 Research Bull., Agr. Exp. Stat., Liniv. Wisconsin, 19 to 24.

Donaldson 1911 Jour. Morph., vol. 22, p. 663.

Dufour 1833 A l'Acad. d. Sc., T. 4, p. 129.

2 Riley and Johannsen 1915 Handbook of Med. Ent. Ithaca, New York.

13 HataI 1917 Carn. Inst. Publ., no. 251.

4 Morguiss 1911 Areh. f. Entw. d. Org., Brl. 32, \$. 169.

5 Donaldson 1911 Jour. Comp. Neur., vol, 21, p. 139.

6 Vernon 1897 J. Physiol, vol. 21, p. 443.

17 Benedtct and Emmes 1915 J. Bio. Chem., vol. 20, p. 253.

18 RubNer 1883 Zeit. f. Biol., Bd. 19, S. 536.

19 Child 1919 Am. J. Physiol., vol. 48, p. 231.

20 Allen 1919 Am. J. Physiol., vol. 49, p. 420.

21 KRoGH 1916 The respiratory exchange of animals and man. Longmans, Green \& Co., London and New York.

22 Meen 1879 Zeit. f. Biol., Bd. 15, S. 425.

23 Clausen 1890 Landwirtschaftl. Jahrb., Bd. 19, s. 893.

24 Matthaer 1904 Trans. Philos. Soc. London, series B, vol. 197, p. 47.

25 Hild 1911 J. Physiol., vol. 43, p. 379.

26 Hrman 1919 Am. J. Physiol., vol. 49, p. 377.

27 LUNd $191 \mathrm{~s}$ Am. J. Physiol., vol. 47, p. 318. 